\title{
REPRESENTASI RELIGI DALAM NOVEL AYAT-AYAT CINTA 2 KARYA HABIBURRAHMAN EL SHIRAZY
}

\author{
Ida Rufaida \\ MTs Raudlatul Muta'allimin Lamongan \\ Telp.085648719592 \\ Pos-el: rufaida04@yahoo.com
}

\begin{abstract}
Abstrak: Penelitian ini bertujuan untuk mendeskripsikan segala hal tentang religiusitas di dalam novel Ayat-Ayat Cinta 2, baik yang berkenaan dengan nilai religi, dimensi religi, serta representasi religi di masyarakat. Data dalam penelitian ini bersumber dari novel Ayat-ayat Cinta 2 karya Habiburrahman El Shirazy, cetakan pertama November 2015, berisi 690 halaman, diterbitkan oleh Republika. Data dikumpulkan dengan teknik kepustakaan dengan menggunakan metode deskriptif kualitatif dengan pendekatan sosiologis. Pada penelitian ini terlihat bahwa nilai religiusitas yang terdapat dalam novel ini adalah nilai ibadah, nilai akhlak, nilai amanah, nilai keteladanan dan ikhlas. selain itu, religiusitas juga terdapat dalam dimensi religi yang meliputi dimensi pengalaman, dimensi pengetahuan agama, dan dimensi pengamalan atau konsekunesi. Representasi religi di masyarakat dalam novel ini terlihat bagaimana usaha untuk mewujudkan suatu kehidupan harmonis, selalu terbentuk dua sikap di antara kalangan penganut agama. Pertama, sikap menghargai dan menghormati penganut agama lain dikarenakan suatu kepentingan, seperti kepentingan politik atau lainnya. Kedua, sikap menghargai dan menghormati penganut agama lain dikarenakan dirinya akan ajaran agama Tuhan. Kesadaran mewujudkan kehidupan harmonis antara penganut agama adalah suatu hal yang sangat penting.
\end{abstract}

Kata kunci: Representasi, Religiusitas, dan Kajian Sosiologi sastra

\begin{abstract}
This study aimed to describe everything about the religiosity of the novel Love Verses 2, both with regard to religious values, religious dimension, as well as the representation of religion in society. The data were derived from novel Love Verses 2 Habiburrahman El Shirazy, first printing November 2015, contains 690 pages, published by Republika. Data collected by technical literature by using descriptive method qualitative sociological approach. In this study, it appears that the value of religiosity contained in this is the value of worship, moral values, the value of the trust, the value of exemplary and sincere. in addition, religiosity is also present in the religious dimension that includes the dimension of experience, knowledge dimension of religion, and the dimensions of practice or Consequences. Representation of religion in society in this novel, seen how efforts to realize a harmonious life, always formed two attitudes among religious circles. First, with respect and respect other faiths because of an interest, such as political or other interests. Second, with respect and respect other faiths because he would be the religious teachings of the Lord. Awareness realize harmony between religions is a very important thing.
\end{abstract}

Keywords: Representation, Religiosity, and literature Sociology Study 


\section{PENDAHULUAN}

Sebuah karya sastra, khususnya novel mengandung nilai cerminan kehidupan manusia yang salah satunya yaitu nilai religi. Nilai religi yaitu mengenai nilai ketuhanan. Religi sebagai sesuatu yang identik dengan hal yang berhubungan dengan ketuhanan, agama, hubungan manusia dengan manusia dan kepercayaan manusia terhadap suatu zat yang Maha Tinggi. Kepercayaan kepada Tuhan merupakan suatu hal mutlak bagi manusia, akan tetapi terdapat manusia yang tidak memercayai adanya Tuhan. Keragaman kepercayaan terjadi karena manusia merupakan makhluk paling sempurna yang diciptakan oleh Allah sebagai makhluk hidup yang memiliki akal dan pikiran. Kepercayaan yang diyakini manusia di antaranya Islam, Kristen, Katolik, Yahudi, Hindu, Budha dan lain-lain.

Setiap negara memiliki jumlah pengikut agama yang berbeda-beda. Contohnya, di Indonesia mayoritas masyarakatnya memiliki kepercayaan terhadap Islam yang artinya kebudayaan dan deskripsi kehidupan di Indonesia berdasarkan kepercayaan Islam, terutama kegiatan-kegiatan dalam beribadah. Di Inggris mayoritas masyarakatnya memiliki kepercayaan terhadap agama Yahudi, Kristen, baik Protestan maupun Katolik, kehidupannya bebas dan hanya terikat terhadap perundang-undangan negara.

Pemilihan novel Ayat-ayat Cinta 2 (selanjutnya disingkat AAC 2) karya Habiburrahman El Shirazy dilatar belakangi adanya keinginan untuk memahami karya sastra yang mengangkat tema religi. Novel ini membahas mengenai sebagian masyarakat di Barat yang tidak terlalu bisa menerima kehadiran Islam, terutama di Inggris setelah kejadian 11 September 2001 dan bom London pada 7 Juli 2005. Novel ini menceritakan tentang perjalanan Fahri, seorang muslim asal Indonesia yang tinggal di negara Barat dengan berbagai tantangan dahwah. Menceritakan bagaimana Fahri berdakwah di Eropa menghadapi kondisi munculnya Islamofobia. Fahri yang menjadi tokoh utama dalam cerita itu, juga diceritakan mengikuti acara debat terbuka. Dalam debat itu pula, Fahri mendapatkan kesempatan menjelaskan bagaimana Islam yang sebenarnya.

Dalam novel tersebut, pengarang lebih banyak mendeskripsikan sisi religi sebagai posisi yang tidak dapat terlepaskan dari kehidupan manusia, terutama agama Islam. Dunia tanpa adanya toleransi agama tidak akan secerah dan lebih baik daripada saat ini. Novel ini diterbitkan November 2015 ditulis berdasarkan pengalaman pengarang saat berkeliling di Amerika dan Bitania Raya Inggris. Novel ini berbeda dengan novel Ayat-ayat Cinta 1 yang merupakan perjalanan spiritual yang nyata dialami oleh pengarang saat berada di Kairo.

Penelitan ini menggunakan pendekatan sosiologi sastra untuk mengkaji novel $A A C 2$. Menurut Wiyatmi (2013:8), pendekatan sosiologi sastra merupakan perkembangan dari pendekatan mimetik yang memahami karya sastra dalam hubungannya dalam realitas dan aspek sosial kemasyarakatan. Sosiologi sastra merupakan hubungan karya sastra dengan masyarakat, yang dituangkan dalam bentuk karya fiktif untuk menggambarkan kehidupan masyarakatnya yang dikaji secara sosiologis. Menurut Durkheim (dalam Masykur, 2011:4) Sosiologi agama mencoba memahami makna yang diberikan oleh masyarakat kepada sistem agama tertentu, dengan meletakkan agama dan keberagaman manusia sebagai gejala sosial. 
Representasi adalah sebuah cara untuk memaknai apa yang diberikan pada benda yang digambarkan. Konsep lama mengenai representasi ini didasarkan pada premis bahwa ada sebuah gap representasi yang menjelaskan perbedaan antara makna yang diberikan oleh representasi dan arti benda yang sebenarnya digambarkan. Hal ini terjadi antara representasi dan benda yang digambarkan. Representasi dalam sastra muncul sehubungan dengan adanya pandangan atau keyakinan bahwa karya sastra sebetulnya adalah cermin, gambaran, bayangan, atau tiruan kenyataan. Dalam konteks ini karya sastra dipandang sebagai penggambaran yang melambangkan kenyataan (memimes) (Teeuw dalam Putra, 2012:25).

Emile Durkheim

memberikan sebuah definisi untuk agama adalah sebagai suatu sistem kepercayaan dan tingkah laku yang berhubungan dengan hal-hal yang dianggap sakral yaitu merupakan hal-hal yang yang dilarang dan dipisahkan, kepercayaan dan perilaku yang mempersatukan semua penganutnya menjadi satu komunitas moral, yaitu berdasarkan nilai-nilai bersama yang disebut umat.

Nilai religi adalah suatu sistem kepercayaan dan tingkah laku yang berhubungan dengan hal-hal yang dianggap sakral yaitu merupakan hal-hal yang yang dilarang dan dipisahkan, kepercayaan dan perilaku yang mempersatukan semua penganutnya menjadi satu komunitas moral, yaitu berdasarkan nilai-nilai bersama yang disebut umat (Emile Durkheim dalam Masykur, 2011). Menurut Fathurrohman (2012:3) jenis nilai-nilai religi yaitu: nilai ibadah, nilai ruhul jihad, nilai akhlak dan kedisiplinan, nilai keteladanan, serta nilai amanah dan ikhlas. Dimensi keberagaman atau religiuitas menurut
Glock dan Stark (dalam Djamaludin dan Suroso, 2011:80), terbagi ke dalam lima macam, yaitu dimensi keyakinan (ideologis), dimensi peribadatan atau praktik agama (ritual), dimensi pengalaman, dimensi pengetahuan agama (intelektual), dan dimensi pengamalan (konsekuen sial).

Sebagai seorang yang berkecimpung di dalam dunia pendidikan, peneliti sangat tertarik untuk menganalisis lebih lanjut bagaimana gambaran keberadaan agama atau religi dalam kehidupan sosial manusia di suatu tempat yang dituangkan dalam tokoh utama. Tokoh utama mengalami perjalanan spiritual yang begitu lekat dengan kehidupannya disuatu tempat. Lingkungan yang sebagian orangnya kurang bisa menerima kehadiran agama yang dianutnya.

Dari paparan di atas, perlu adanya penelitian yang bertujuan untuk mendeskripsikan (1) nilai-nilai religi (2) dimensi religi, dan (3) representasi religi di masyarakat dalam novel Ayat-ayat Cinta 2 karya Habiburrahman El Shirazy.

\section{METODE PENELITIAN}

Penelitian ini menggunakan metode deskriptif kualitatif, dengan pendekatan sosiologis. Menurut Endraswara (2011:79), pendekatan sosiologi sastra berupa penelitian yang berfokus pada masalah manusia karena sastra sering mengungkapkan perjuangan umat manusia dalam menentukan masa depannya. Dalam hal ini mengarah pada konteks religi. Pendekatan sosiologis merupakan pendekatan tentang interelasi antara agama dengan masyarakat serta bentuk-bentuk interaksi yang terjadi diantara mereka. Kekuatan sosial organisasi dan stratifikasi sosial mempengaruhi masyarakat. Pendekatan sosiologis dalam penelitian ini dimaksudkan dapat menjelaskan hal-hal 
religiusitas yang terdapat dalam novel $A A C 2$ dengan mengaitkannya dengan kehidupan. Data dalam penelitian ini adalah representasi religi yang meliputi: nilai-nilai religi, dimensi religi, dan representasi religi di masyarakat dalam $A A C 2$ karya Habiburrahman El Shirazy. Sumber data dalam penelitian ini adalah novel $A A C 2$ karya Habiburrahman El Shirazy, cetakan pertama November 2015, berisi 690 halaman, diterbitkan oleh Republika.

Teknik pengumpulan data yang digunakan dalam penelitian ini yaitu dengan menggunakan teknik kepustakaan. Istilah studi kepustakaan digunakan dalam ragam istilah oleh para ahli, di antaranya yang dikenal adalah: kajian pustaka, tinjauan pustaka, kajian teoritis, dan tinjauan teoritis. Penggunaan istilah-istilah tersebut pada dasarnya merujuk pada upaya umum yang harus dilalui untuk mendapatkan teori-teori yang relevan dengan topik penelitian. Bila kita telah memperoleh kepustakaan yang relevan, maka segera untuk disusun secara teratur untuk dipergunakan dalam penelitian. Oleh karena itu studi kepustakaan meliputi proses umum seperti mengidentifikasikan teori secara sistematis, penemuan pustaka, dan analisis dokumen yang memuat informasi yang berkaitan dengan topik penelitian. Berdasarkan penelitian tersebut, berbagai data yang dikumpulkan berupa artikel, catatan, buku, jurnal, dan sumber lainnya.

Dalam kegiatan analisis data penelitian ini dilakukan dengan beberapa tahap: pemilihan data, pengklasifikasian data, pendesrisian data, interpretasi data, dan inferensi data. Adapun langkahlangkah dalam inferensi data direalisasikan dalam tahap-tahap berikut: (1) mencari referensi buku-buku yang berkaitan dengan judul yang telah dipakai penulis, (2) membaca dan memilih halhal yang berkaitan dengan judul tersebut,
(3) mencatat serta mengumpulkan datadata yang berupa catatan yang telah dikumpulkan, (4) mengklasifikasi nilai religi, dimensi religi, serta representasi religi di masyarakat dalam novel $A A C 2$.

\section{HASIL PENELITIAN}

\section{Representasi Religi Novel AAC 2}

Representasi religi merupakan perwakilan tentang hal religi, baik nilainilai religi, ataupun dimensi religi. Pada novel ini, penggambaran religi ditunjukkan bukan dalam ritual ibadah saja, tetapi bentuk keyakinan terhadap Tuhan yang diaplikasikan dalam kehidupan sehari-hari dengan menjalankan ajaran agama.

\section{Nilai Religi}

Pada novel $A A C 2$ memiliki lima nilai religi, yakni nilai ibadah, nilai ruhul jihad, akhlak dan kedisiplinan, keteladanan, dan nilai amanah dan ikhlas. Walaupun tidak diperlihatkan secara jelas melalui gerakan hidup tokoh.

\section{Nilai Ibadah}

Menurut Fathurrohman (2012:4) Ibadah merupakan bentuk penyembahan manusia kepada Tuhan. Bentuk penyembahan terhadap Tuhan bukanlah hanya seperti sholat bagi umat islam, berdoa di gereja bagi umat Kristiani atau ritual lainnya. Bentuk ibadah manusia kepada Tuhan dapat dilakukan dalam kegiatan sehari-hari, terutama sesuai ajaran agama masing-masing. Contohnya seperti berdzikir, membaca Alquran, mengaji, berdoa, dan lainnya. Nilai ibadah dalam novel ini tidak tertuju hanya pada tokoh utama, tetapi juga pada tokoh tambahan lainnya.

"Ya Allah, berikan hamba taufik untuk bisa mengamalkan wasiat yang baik ini." (AAC $2: 11)$

"Jika ini memang ajalku, aku ikhlas ya Allah. Namun terimalah kematianku ini sebagai kematian orang yang berjuang di jalan-Mu. Terimalah diriku dalam 
barisan orang-orang yang mati syahid," doa Fahri dalam hati. (AAC 2 : 504)

Pada kutipan di atas, terlihat jelas bahwa Fahri merupakan seorang muslim yang taat dalam menjalankan perintah agama. Hal ini terlihat saat Fahri secara mengejutkan diberi pertanyaan oleh mahasiswanya tentang alasan orang muslim menyukai bom bunuh diri. Selain itu ketaatan pada Tuhan juga ditunjukkan pada kutipan kedua, ketika ia dicekik oleh Baruch hingga kesulitan bernafas.

Doa merupakan salah satu bentuk ketakwaan seorang hamba kepada Tuhan. Dengan berdoa, Allah akan memberikan pertolongan dan mengabulkan segala permintaan. Karena apabila tidak berdoa, maka Allah pun akan marah terhadap hamba-Nya.

Bukan hanya Islam yang berdoa sebagai wujud ketakwaan kepada Tuhan, tetapi agama lain juga berdoa sebagai wujud ketakwaannya. Nenek Catarina memiliki aktivitas beribadah di gereja setiap minggu.

Ibadah Sabat di Sinagog itu satu-satunya hiburanku di hari tua. Aku harus ke sana (AAC:101)

Sabat yang dilakukan Nenek Catarina merupakan bentuk peribadatan diri kepada Tuhannya dengan berdoa. Fahri dan Misbah bukanlah sosok yang tidak berdoa kepada Tuhan, tetapi agama yang mereka berdua percaya dan yakini berbeda dengan Nenek Catarina. Mereka hanya mau menolong mengantarkan Nenek Catarina yang ingin beribadah. Kegiatan yang dilakukan Fahri dan Nenek Catarina adalah kegiatan yang bermakna nilai dan ritual ibadah dengan cara dan keyakinan masing-masing.

\section{Nilai Ruhul Jihad}

Ruhul Jihad merupakan dorongan jiwa kita sebagai manusia untuk melakukan yang terbaik secara sungguhsungguh dalam bekerja. Terkadang manusia di dalam hubungannya dengan sesama manusia, seperti saling membantu dalam kebaikan ataupun membantu saling menjaga kehidupan, tidak dilakukan dengan sungguh-sungguh. Begitupun hubungan manusia dengan Tuhan, kita sering kali tidak secara kaffah menjalankan segala ajaran Tuhan dengan baik ataupun sungguh-sungguh (Fathurrohman, 2012:4). Pada novel ini, nilai Ruhul Jihad terepresentasikan pada usaha Fahri dengan sungguh-sungguh untuk membantu Sabina sekuat tenaga untuk tetap hidup dan tidak berputus asa. Ini terlihat pada kutipan berikut.

“.....Tenang saja, sister. Klinik di sini bertugas menyembuhkan sakit Anda, bukan menyerahkan anda kepada polisi atau petugas imigrasi. Anda tidak usah khawatir. Setelah sembuh, saya ingin Anda tinggal bersama kami, kami akan urus semua masalah anda sehingga anda di sini legal. (AAC 2 : 201)

“.....Jangan berkata seperti itu, sister. Perkenankanlah saya melakukan itu demi ibadah kepada Allah. Jangan kau tolak orang yang ingin beribadah kepada Allah. (AAC 2 : 201)

Berusaha dengan sungguh-sungguh untuk memperoleh keselamatan hidup merupakan salah satu usaha paling keras yang dilakukan manusia. Terutama yang dilakukan oleh Fahri. Tidak putus asa dan terus berusaha menyemangati Sabina dengan sungguh-sungguh menunjukkan hablum min al-anas yang baik karena menunjukkan usahanya.

\section{Nilai Akhlak dan Kedisiplinan}

Akhlak merupakan sifat atau sikap yang dilakukan selama hidup di dunia. Berdasarkan pengetahuan agama, akhlak terbagi menjadi dua, yakni akhlak terpuji dan akhlak tercela. Religiusitas seseorang dapat menentukan akhlak yang terdapat di dala dirinya, akankah memiliki akhlak terpuji ataupun akhlak tercela. Akan tetapi, terbentuknya akhlak manusia dapat diketahui berdasarkan bagaimana terbentuk sejak kecil. Mulai dari apa yang diajarkan dan dicontohkan kedua 
orangtua kepada anak, lingkungan sosial tempat manusia dibesarkan, peran orangtua dalam setiap nasihat yang tidak mengekang pilihan hidup anak untuk menjadi lebih baik.

Dalam novel $A A C$ 2, pengarang novel tidak menonjolkan akhlak terpuji hanya pada tokoh utama saja, melainkan pada tokoh-tokoh lainnya yang berada dalam novel tersebut. Fahri memiliki akhlak terpuji dan dapat kita lihat dengan dirinya yang selalu berdoa dan mengingat Tuhan di saat apapun. Ia tidak pernah mengeluh atas perlakuan Baruch atau orang Yahudi yang menganggap umat muslim sepertinya adalah keledai-keledai bodoh sebagai Amalek. Bahkan dia siap berdiskusi terbuka tentang Amalek karena kewajibannya sebagai muslim untuk membela agama keyakinannya. Ini terlihat dalam kutipan berikut.

“.....Ya seperti itulah mereka! Keledaikeledai bodoh yang hanya menyesaki isi dunia saja." (AAC $2: 258)$

".... saya Fahri, pengajar di The University of Edinburgh. Maaf tadi kalian memperbincangkan kaum yang kalian sebut amalek. Mohon maaf, pandangan kalian itu tidak benar, bahkan boleh dikatakan picik. Saya siap berdiskusi dengan kalian tentang konsep amalek kalian itu, kapan saja. Jika berminat, kontek saya, terima kasih. (AAC 2 : 262)

Segala tindakan yang dilakukan Fahri adalah suatu bentuk usaha pembelaan terhadap agamanya dan mengklarifikasikan semua judgement buruk kepada Islam yang menganggap orang Islam adalah Amalek, salah satunya karena teroris.

Akhlak terpuji ditunjukkan oleh tokoh lainnya, yaitu Tuan Taher. Ia begitu ramah dan sopan kepada siapapun. Termasuk kepada Fahri dan Misbah yang baru pertama kali dijumpai ketika di Masjid, walaupun belum dikenal dengan baik.
“.....Bagaimana kalau saya undang kalian minum teh di rumah saya sambil menikmati Scotch Pie dan roti Bridie buatan putri saya? Rasanya sedap sekali. (AAC 2 :84)

"Tuan Taher sudah membuka pintu rumahnya dan mempersilahkan masuk (AAC $2: 88)$

Pada kutipan di atas, terlihat Tuan Taher begitu ramah kepada tamunya serta disambut dengan penuh senyum.

\section{Nilai Keteladanan}

Keteladanan merupakan tindakan yang dapat diambil hikmahnya dan diaplikasikan dalam kegiatan. Pada novel $A A C 2$ ini, keteladanan dapat terlihat pada sosok Fahri, dikarenakan kegigihan mencari kabar tentang istrinya yang hilang di Palestina. Serta selalu berusaha memberi harapan hidup kepada tetangga dan orang-orang di sekitarnya yang hampir putus asa untuk meraih apa yang mereka inginkan meski ia sangat dibenci mereka. Ini terlihat pada kutipan berikut.

"Jangan mengumpat begitu, Paman! Kita belum tahu apa yang menjadi sebab Kaira sampai sedemikian membenci kita. Apakah kita punya salah kepadanya? Apakah karena informasi tidak benar yang ia terima tentang Islam dan umat Islam? Kebencian itu tidak perlu kita sikapi dengan kebencian yang sama. Kita harus tunjukkan dengan bukti nyata bahwa kita jauh dari yang dia sangka" (AAC $2: 158$ )

Dalam kutipan di atas, terlihat keteladanan tokoh Fahri yang tidak dendam atas perlakuan Kaira, dia sikapi dengan kebaikan dan terpacu untuk membuktikan bahwa Islam tidak seperti yang Kaira bayangkan.

Keteladanan juga dapat terlihat pada tokoh lainnya, yaitu Jason. Dirinya yang tetap meyakini Kristen sebagai agamanya walaupun kegundahan akhirnya menghampirinya. Ia melihat kaum muslimin tidak seperti yang dibayangkannya, sikap ramah tamah, baik hati, dan manghargai perbedaan 
agama yang dimiliki Fahri, membuat Jason ingin mendalami islam. Ini terlihat dalam kutipan berikut.

..."Sudah satu pekan ini aku punya keinginan yang terus bergemuruh dalam dada."

"aku ingin pindah agama Islam." (AAC 2 :462)

\section{Nilai Amanah dan Ikhlas}

Amanah adalah sebuah pesan yang wajib disampaikan kepada orang lain. Tokoh Fahri yang merupakan tokoh amanah dalam menjalankan tugas yang diembankan kepada dirinya. Fahri melaksanakan dengan ikhlas dan amanah tugas yang diberikan oleh Profesor Charlotte dan Profesor Stevens.

"Sebelum kita diskusi panjang lebar tentang filologi, satu hal yang harus kalian catat. Hal pertama yang harus dimiliki seorang filologi adalah amanah. Saya diminta Profesor Charlotte untuk mengeluarkan dari kelas ini, siapa saja yang belum membaca dua buku itu. Tanpa pandang bulu. Maka saya harus amanah. Tadi Juu suh sudah saya keluarkan dari kelas ini. Dan selanjutnya, adalah kewenangan saya untuk memberinya kesempatan masuk kembali ke dalam kelas. Amanah Profesor Charlotte sudah saya laksanakan. Dan prinsip saya untuk tidak menolak siapa saja yang mau belajar bersama saya, juga saya lakukan." (AAC $2: 5-6)$

"...Oxford Debating Union minta seorang akar Islam, Timur Tengah, dan Asia Tenggara untuk berdebat. Awalnya saya minta Profesor Ted Stevens. Tapi dia tidak bisa. Saya tak punya pilihan lain selain kamu, Fahri. Saya sangat yakin kamu bisa berdebat di forum debat paling prestisius di Britania Raya ini.... (AAC 2 : 204)

Menurut Fathurrohman (2012:6) Ikhlas merupakan perbuatan tanpa mengharapkan suatu balasan apapun dari manusia dan hanya mengharapkan keridhaan Allah semata. Ikhlas pun tindakan tanpa penuh keluh kesah dan berlapang dada untuk melakukan sesuatu.
Pada novel ini, keikhlasan terlihat pada dua tokoh yaitu Sabina dan Hulya.

Sabina yang sedang mendapat ujian yang tak pernah terkira olehnya yaitu terpisah dari suami, serta badan terluka, muka buruk, dan sebagainya. Dia tak putus asa dengan ujian yang sedang dihadapinya tersebut. dia selalu mengingat Allah dalam kejadian tersebut. selain itu, dirinya melapangkan hati atau mengikhlaskan akan ujian yang diberikan Allah kepadanya dengan tetap berusaha bertahan hidup.

“......Mereka menganggapku bagian dari teroris Palestina yang mengancam Israel. Mereka menyangkal semua penjelasanku. Aku dianggap mata-mata berbahaya. Aku dijebloskan dari satu penjara ke penjara lain. Sampai aku dijebloskan ke penjara perempuan....(ACC $2: 685)$

Di balik cadarnya, perempuan itu berjuang untuk megalahkan kesedihannya. Jianya ingin membuang nafsu sedihnya, mengiringi para darvish itu menari, dan perempuan itu tak lain dan tak bukan adalah Sabina.. (AAC 2 : 594)

Berdasarkan kutipan di atas, Sabina berusaha ikhlas melihat Fahri (suaminya) menikah dengan Hulya, wanita yang diajukkan untuk menjadi istri Fahri. segala kesulitan yang menghampiri, hati dan pengharapan tetap tertuju kepada Allah dengan ikhlas melapangkan hati atau mengikhlaskan bukan berarti pasrah, tetapi suatu usaha maksimal yang hasilnya diserahkan kepada Tuhan.

\section{Dimensi Religi}

Dimensi religi adalah ruang bentuk dari religi. Dimensi religi tidak jauh berbeda dengan nilai religi, yang membedakannya hanya pada titik fokus dimensi religi yaitu pada bentuk religi. Menurut Glock dan Stark (dalam Djamaludin dan Suroso, 2011:80), dimensi religi terbagi menjadi lima, yaitu dimensi keyakinan, dimensi praktik agama, dimensi pengaaman, dimensi 
pengetahuan agama, dan dimensi pengamalan atau konsekuensi. Akan tetapi pada novel ini analisis dimensi religi lebih difokuskan penelitiannya pada tiga dimensi saja. Hal ini dikarenakan dua dimensi lainnya sudah lebih terdeskripsikan pada nilai religi. Ketiga dimensinya yaitu dimensi pengalaman, dimensi pengetahuan agama, dan dimensi pengamalan atau konsekuensi.

\section{Dimensi Pengalaman}

Dimensi ini merupakan dimensi di saat seseorang mengalami pengalaman spiritualitas yang terjadi terhadap diri mereka terkait ketuhanan (Glock dan Stark dalam Thontowi, 2014:4). Pada novel ini, dimensi pengalaman dialami oleh Fahri saat dia harus bertahan hidup di lingkungan yang kurang bisa menerima keberadaan dirinya, perpisahan untuk pertama kali dengan sang istri saat berada di luar negeri. Fahri hanya bisa menangis terisakisa setiap kali mengingat Aisha. Semua itu menguji kekuatan iman Fahri. Akankah dia tetap mengingat Tuhan dan meminta tolong kepada-Nya ataukah berkeluh kesah karena ketetapan takdir Tuhan yang luar biasa di luar dugaan.ini terlihat pada kutipan berikut.

“....Kemudian terisak-isak mengingat Aisha. Apakah Aisha telah menyusul Maria? Ia tidak tahu harus seperti apa mendoakan Aisha. Ia terus berdoa kepada Allah agar dia terus mengasihi istrinya, dan terus menyelimutinya dengan selimut rahmat dan taufiq, baik ia masih hidup ataukah telah tiada. Fahri lalu melanjutkan bacaannya dan menuntaskan hingga selesai juz tujuh belas. (AAC $2: 17$ )

Berdasarkan kutipan di atas, terlihat bahwa takdir Tuhan besar adanya. Fahri hanya dapat berusaha tapi tidak dapat merubah takdir yang telah ditetapkan Tuhan kepadanya. Maka dari itu, manusia harus kuat keimanannya terhadap Tuhan. Apabila lemah keimanan, maka takkan ada usaha yang dilakukan, hanya berkeluh kesah terhadap Tuhan dan bahkan berpaling dari-Nya.

\section{Dimensi Pengetahuan Agama}

Dimensi ini merupakan dimensi yang terkait dengan pengetahuan yang dimiliki seseorang (Dimensi ini merupakan dimensi yang terkait dengan pengetahuan yang dimiliki seseorang (Glock dan Stark dalam Thontowi, 2014:4). Dalam novel $A A C$ 2, terdapat bentuk pengetahuan agama yang tidak diajarkan secara umum selama dibangku pendidikan, dan hanya dapat diketahui apabila seseorang membaca buku dan diberitahu siapapun yang mengetahui sejarah Islam lebih dahulu. Ini terlihat pada kutipan berikut.

"Kita tidak cukup hanya melarang saudara-saudara kita mengemis. Kita semua umat Islam, bertanggungjawab atas nasib mereka. Kita harus introspeksi. Sudah genapkah zakat kita? Ada hak mereka dalam harta kita. Apakah kita yang nasibnya lebih baik telah membuat program riil untuk perbaikan nasib mereka? Di mana kita letakkan hadits Nabi, Man la yahtam bi amril muslimin fa laisa minhum. Siapa yang tidak perduli pada urusan muslimin maka tidak termasuk golongan mereka? (AAC 2 : 85)

Pada kutipan di atas, sebuah sejarah Islam yaitu salah satunya mengenai seorang budak yang menginginkan kesetaraan, akhirnya menemukan hal yang diinginkannya ketika dirinya melihat Islam. Dengan kata lain semua manusia memiliki hak yang sama di dunia ini, yang membedakannya hanya amal ibadah dan tak membedakan perbedaan ras, gender, ataupun sosial.

Pengetahuan lain yang terdapat dalam novel ini adalah mengenai Alquran yang hanya dijadikan aksesoris saja pada zaman sekarang. Berikut kutipannya.

"Ini kerja peradaban, Bah. Secara konsep peradaban Islam tidak ada tandingannya. Masalahnya baha umat Islam sudah sedemikian dijauhkan 
dari ruh Alquran dan Sunnah. Apa yang diinginkan William Ewart Gladstone itu kini terjadi."

"William Ewart Gladstone pernah terang-terangan berkata kepada media Inggris, Selama kaum muslim memiliki Alquran, kita tidak akan bisa menundukkan mereka. Kita harus mengambilnya dari mereka, menjauhkan mereka dari Alquran, atau membuat mereka kehilangan rasa cinta kepada kitab suci mereka itu.

"Dan ucapan Gladstone itu kini terjadi, Bah. Umat Islam sibuk menjadikan Alquran sebagai aksesoris saja.... (AAC 2 : 94)

Pada kutipan di atas, menunjukkan bahwa pengetahuan agama bukan mengenai ajaran saja, tetapi pada bagaimana cara kita seharusnya mengamalkannya. Karena agama itu pondasi kita menuju yang lebih baik.

\section{Dimensi Pengamalan dan Konsekuensi}

Dimensi ini mengenai konsekuensi terhadap keyakinan suatu agama yang dipercayai, serta komitmen terhadap agama tersebut. pada novel ini terlihat jelas sejak peristiwa 11 September 2001 dan bom London 7 Juli 2005.

Seorang muslim mengalami kesulitan di dalam hidupnya dengan teruji keyakinan agama Islam. Mereka seolah diteror dengan kebencian-kebencian karena kejadian tersebut. Konsekuensi pertama yang harus diterima Fahri adalah menghadapi teror Kaira dengan coretancoretan yang Kaira tulis di kaca mobilnya karena kebenciannya terhadap orang Islam yang dianggapnya telah membunuh ayahnya dalam Bom London. Ini terlihat pada kutipan berikut.

Fahri mengisyaratkan agar melihat coretan di kaca depan mobil SUV. Paman Halusi tersentak, coretan itu berbunyi: ISLAM SANATIC! (AAC 2:31)

Lihat ini Hoca. Baca tulisannya!"

Di kertas HVS itu ada tulisan pakai spidol merah tebal yang bunyinya: MUSLIM = MONSTER! (AAC 2 : 77)

\section{Representasi Religi di Masyarakat}

Religiusitas merupakan suatu hal yang berhubungan terhadap Tuhan dan suatu hal di luar pemikiran rasional manusia yang tidak dapat diungkap oleh indra dan terkait terhadap ajaran agama. Religiusitas yang terjadi di kehidupan masyarakat dapat berupa kegiatan seharihari yang berhubungan kepada Tuhan maupun terkait agama (Thontowi, 2014:1).

Seorang manusia yang hidup di bumi Allah yang Maha Pemurah lagi Maha Penyayang, setiap detik kehidupannya dapat mendekatkan hatinya kepada Allah, memohon petunjuk dan kekuatan dalam kehidupan setiap hari. Dan manusiapun berhubungan langsung kepada Allah tanpa perantara manusia untuk berdoa kepada Tuhannya.

Doa merupakan suatu bentuk komunikasi antara manusia dengan Tuhan. Baik dalam meminta petunjuk dan kekuatan, maupun menuangkan keluh kesahnya yang terjadi di kehidupannya terhadap Allah ataupun memohon ampunan. Dalam novel $A A C 2$ terlihat pada kutipan berikut.

"Dalam sujud panjangnya Fahri mengadu kepada Tuhannya tentang kerinduannya keada Aisha. Ia meminta kepada Tuhan agar mengampuni dirinya jika dalam kerinduannya itu terdapat kezaliman pada dirinya sendiri. Ia meminta kepada Tuhan agar dirinya jangan diserahkan kepada hawa nafsunya sedetikpun. Ya Наyyu ya Qayyum birahmatika astaghitsu ashlih li nafsi wa la takilni ila nafsi tharfata ain. Aamiin.(AAC 2 : 238)

Pada kutipan di atas, begitu jelas tokoh Fahri yang sedang merindukan istrinya yang lama menghilang, selalu berdoa kepada Allah, meminta petunjuk dan memohon ampun serta meminta kekuatan dalam menjalani cobaan yang 
dia terima. Ini merupakan salah satu nilai religiusitas yang teraplikasikan dalam kehidupan masyarakat.

Usaha untuk mewujudkan suatu kehidupan harmonis, selalu terbentuk dua sikap di antara kalangan peganut agama. Pertama, sikap menghargai dan menghormati penganut agama lain dikarenakan suatu kepentingan, seperti kepentingan politik atau lainnya. Kedua, sikap menghargai dan menghormati penganut agama lain dikarenakan dirinya akan ajaran agama Tuhan. Kesadaran mewujudkan kehidupan harmonis antara penganut agama adalah suatu hal yang sangat penting.

"Pikirkan baik-baik. Lalu bicarakan hal ini baik-baik dengan mamamu, bicarakan juga dengan Keira. Pindah agama itu bukan perkara ringan.” (AAC 2 : 463)

Pada kutipan di atas, sikap saling menghargai dan menghormati kepercayaan agama orang lain terlihat dari Fahri yang tidak memaksakan Jason agar seperti dirinya, menjadi seorang muslim. Dia memberi kesempatan kepada Jason untuk memikirkan pilihannya untuk masuk Islam. Agar dia benar-benar meneguhkan imannya dan nantinya tidak bermain-main dengan syahadat.

\section{PEMBAHASAN}

Berdasarkan hasil analisis data, penelitian ini menghasilkan tiga temuan. Pertama, nilai religi, novel $A A C 2$ memiliki kegiatan-kegiatan kesehariannya yang bernilai religiusitas yakni nilai ibadah, nilai ruhul jihad, akhlak dan kedisiplinan, keteladanan, dan nilai amanah dan ikhlas. Kedua, dimensi religi, kegiatan-kegiatan yang digambarkan dalam novel ini memiliki makna yang mangandung religiusitas antara lain dimensi pengalaman, dimensi pengetahuan agama, dan dimensi pengamalan atau konsekuensi. Ketiga, Adanya religi di masyarakat, novel $A A C$ 2 memperlihatkannya bahwa tidak adanya paksaan dalam beragama. Pada religi di masyarakat, novel $A A C 2$ memperlihatkan adanya sikap saling menghargai dan menghormati kepercayaan agama orang lain.

Hasil penelitian ini searah dengan penelitian yang pernah dilakukan sebelumnya oleh Hakim (2012) yang berjudul Representasi Ikhlas dalam film Emak Ingin Naik Haji (Analisis Semiotik Terhadap Tokoh Emak). Kajian ini mendeskripsikan secara mendalam representasi ikhlas. Dari hasil analisis peneliti menemukan tanda-tanda atau gambaran ikhlas melalui tokoh Emak, yaitu: 1) pantang menyerah, 2) orang yang ikhlas hatinya baik dan lembut, 3) istiqomah, 4) berusaha membantu orang lain, 5) selalu memaafkan kesalahan orang lain, 6) tidak membeda-bedakan dalam pergaulan, 7) Tawakkal, 8) Bersyukur. Hal yang membedakan penelitian ini dengan penelitian yang saya lakukan adalah fokus penelitiannya. Penelitian tentang representasi juga pernah dilakuan oleh Herwandito (2013) yang berjudul Representasi Perempuan dalam Film Sang Penari (Kajian Semiotika Roland Barthes). Kajian ini menggambarkan representasi perempuan yang terkandung dalam film "Sang Penari" dengan cara menganalisis simbol-simbol yang ada pada tiap adegan yang dapat menggambarkan representasi perempuan secara verbal maupun nonverbal. Berdasarkan hasil analisis, dapat diketahui bahwa film Sang Penari menggambarkan perempuan sebagai penari, ibu rumah tangga, pelacur, bahkan perempuan sebagai pihak yang tertindas. Sehingga terlihat bahwa perempuan sangat berperan dalam segala bidang dan penempatan perempuan masih menjadi objek utama di dalamnya. Relevansi dengan penelitian yang saya lakukan adalah persamaan dalam mengkaji representasi. Selain itu ada juga 
penelitian Ariyadih (2013) yang berjudul "Nilai Religius Pada Novel Opera Van Gontor Karya Amroeh Adiwijaya dan Implikasinya Terhadap Pembelajaran Sastra Indonesia". Relevansi penelitian tersebut dengan penelitian yang akan dilakukan berupa persamaan hal religius yang merupakan analisisnya. Pada penelitian ini, objektifitas yang dikaji begitu berbeda dengan judul yang diajukan. Pada penelitian Ariyadih, seorang santri disebuah pesantren, yaitu di Pesantren Gontor dan analisisnya disesuaikan sekali dengan syarat-syarat sebuah novel dikatakan religi.

Dari hasil tinjauan penelitian terdahulu, ditemukan persamaan dan perbedaan antara penelitian terdahulu dengan penelitian yang saya lakukan saat ini. Persamaan antara penelitian terdahulu dengan penelitian yang saya lakukan adalah fokus yang diteliti, yaitu representasi dan religi. Perbedaan antara penelitian terdahulu dengan penelitian yang saya lakukan sebagai berikut. Pertama, penelitian yang dilaksanakan Hakim (2012) difokuskan untuk mengetahui representasi hanya pada nilai religi yang berkaitan dengan ikhlas saja. Kedua, penelitian yang dilaksanakan oleh Ariyadih (2013) difokuskan untuk mengetahui nilai religi dan impilikasinya terhadap pembelajaran. Sedangkan dalam penelitian novel $A A C 2$ yang saya lakukan ini tidak hanya menganalisis representasi atau gambaran mengenai nilai religi, tetapi juga dimensi religi dan gambaran religi di masyarakat.

\section{SIMPULAN DAN SARAN}

Berdasarkan penelitian yang telah dilakukan dalam novel $A A C 2$, penulis dapat menarik simpulan bahwa religi yang terepresentasikan dalam novel $A A C$ 2 yaitu terbagi ke dalam tiga ranah. Nilai religi, dimensi religi, dan religi di masyarakat. Pada nilai religi, novel $A A C$
2 memiliki kegiatan-kegiatan kesehariannya yang bernilai religiusitas. Contoh pada nilai keteladanan, nilai ini dicontohkan oleh Fahri yang rela membantu menyelamatkan nyawa Sabina dan tidak membiarkan mimpi Kaira dan Jason hilang begitu saja, walaupun dirinya begitu di benci Kaira dan Jason. Pada dimensi religi, kegiatan-kegiatan yang digambarkan dalam novel ini memiliki makna yang mangandung religiusitas, contohnya pada dimensi konsekuensi yag ditunjukkan oleh tokoh Fahri yang tetap teguh membela Islam dalam diskusi pandangan Yahudi terhadap Amalek walaupun banyak konsekuensi yang diterima. Keteguhan hati terhadap agama Allah menunjukkan makna dari sebuah hubungan manusia dengan Tuhan-Nya. Ada religi di masyarakat, novel $A A C \quad 2$ memperlihatkannya bahwa tidak adanya paksaan dalam beragama. Pada religi di masyarakat, novel $A A C \quad 2$ memperlihatkan bahwa sikap saling menghargai dan menghormati kepercayaan agama orang lain, ini terlihat dari Fahri yang tidak memaksakan Jason agar seperti dirinya, seorang muslim dan memberi kesempatan kepada Jason untuk memikirkan pilihannya untuk masuk Islam atas dasar sebuah dukungan yang baik agar dia benar-benar meneguhkan imannya dan nantinya tidak bermainmain dengan syahadat. Selain itu juga ditunjukkan dengan kebaikan Fahri yang akhirnya menyadarkan Kaira bahwa tidak sepatutnya ia membenci orang muslim hanya karena agama Islam dianggap sebagai pembunuh mimpinya.

Peneliti berharap nilai religius dan inspirasi yang terdapat dalam novel $A A C$ 2 hendaknya dapat diaplikasikan dalam kehidupan nyata kita. Berkaitan dengan peneliti selanjutnya, peneliti berharap peneliti selanjutnya dapat mengkaji representasi religi sosial lain yang lebih 
menarik untuk diteliti. Karena penelitian sastra dalam novel AAC 2 tidak hanya dapat diteliti dengan tinjauan sosiologi sastra. Sehingga sangat di sarankan untuk dikembangkan ke dalam penelitian lainnya seperti semiotik dan lainnya.

\section{DAFTAR RUJUKAN}

Ancok, Djamaludin dan Fuat Nashori Suroso. 2011. Psikologi Islami; Solusi Islam atas Problem-problem Psikologi. Yogyakarta: Pustaka Pelajar.

Ariyadih. 2013. Nilai Religiusitas dalam Novel Opera Van Gontor Karya Amroeh Adiwijaya dan Implikasinya Terhadap Pembelajaran Sastra di Sekolah. (online). Diakses 03 Maret 2016.

Durkheim, Emile. 2011. The Elementary Forms of The Religious Life (Terjemahan Ridan Muzir). Jogjakarta: IRCiSoD.

Endraswara, Suwardi. 2011. Metodologi Penelitian Sastra: Epistemologi, Model, Teori, dan Aplikasi. Yogyakarta: CAPS.

El Shirazy, Habiburrahman. 2015. Ayatayat Cinta 2. Jakarta: Republika.

Fathurrohman, Muhammad. Kategori Nilai Religisitas. (online). http://muhfathur rohman.ordpress.com $/ 2012 / 11 / 12 / \mathrm{k}$ ategorisasi-nilai-religius/. Diunduh pada 14 Maret 2016.

Fauzi, Masykur Afif. 2011. Sosiologi Agama dalam Konsepsi Mark. (online).

https://didanel.wordpress.com/2011

/06/23/sosiologi-agama-dalam-

konsepsi-mark/ Diunduh 25 April 2016.

Hakim, Rochman Nur. 2012. Representasi Ikhlas dalam film Emak Ingin Naik Haji (Analisis Semiotik Terhadap Tokoh Emak). (online). http://digilib.uinsuka.ac.id/7847/1/

BAB\%20I,\%20IV,\%20

DAFTAR\%20PUSTAKA.pdf.

Diakses 15 Februari 2016.

Herwandito. 2013. dari Program Studi Komunikasi FISKOM-UKSW yang berjudul Representasi Perempuan dalam Film Sang Penari (Kajian Semiotika Roland Barthes). (Online). Diunduh 5 Mei 2016.

Putra, I Gede Gita Purnama Arsa. 2012. Representasi Multikulturalisme dalam Trilogi novel "Sembalun Rinjani” Karya Djelantik santha. Bali: Program Magister Konsentrasi Wacan Sastra Universitas Udayana. (online). Diakses 14 Februari 2016.

Thontowi, Ahmad. 2014. Hakekat Religiusitas. (online). http://sumsel.kemenag. go.id/file/dokumen/hakekatreligiusi tas.pdf. Diunduh 25 Mei 2016.

Wiyatmi. 2013. Sosiologi Sastra: Teori dan Kajian terhadap Sastra Indonesia. ___ K Kanwa Publisher. 